\title{
Transposition
}

Musique et Sciences Sociales

Tanya L. Saunders, Cuban Underground Hip-hop: Black Thoughts, Black Revolution, Black Modernity

Austin (TX), University of Texas Press, 2015.

\section{Carlos Dávalos}

\section{OpenEdition}

\section{Journals}

Electronic version

URL: http://journals.openedition.org/transposition/2231

DOI: 10.4000/transposition.2231

ISSN: 2110-6134

Publisher

CRAL - Centre de recherche sur les arts et le langage

Electronic reference

Carlos Dávalos, «Tanya L. Saunders, Cuban Underground Hip-hop: Black Thoughts, Black Revolution, Black Modernity », Transposition [Online], 7| 2018, Online since 15 September 2018, connection on 25 September 2020. URL : http://journals.openedition.org/transposition/2231 ; DOI : https://doi.org/ 10.4000/transposition.2231

This text was automatically generated on 25 September 2020

\section{(c) (†) (2)}

La revue Transposition est mise à disposition selon les termes de la Licence Creative Commons Attribution - Partage dans les Mêmes Conditions 4.0 International. 


\title{
Tanya L. Saunders, Cuban Underground Hip-hop: Black Thoughts, Black Revolution, Black Modernity
}

Austin (TX), University of Texas Press, 2015.

\author{
Carlos Dávalos
}

\section{REFERENCES}

Tanya L. Saunders, Cuban Underground Hip-hop: Black Thoughts, Black Revolution, Black Modernity, Austin (TX), University of Texas Press, 2015.

1 Dr. Tanya Saunders' new publication, Cuban Underground Hip-hop: Black Thoughts, Black Revolution, Black Modernity, is a critical recollection of arts-based activism channeled to critique colonial legacies in contemporary Cuba. The study has the first generation of members of the Cuban Underground Hip-Hop Movement (CUHHM) at its center. More than a decade of fieldwork resulted in the author's immersive integration into Habana's everyday social life and Cuba's hip-hop scene. This physical and geographical presence is essential to Dr. Saunders vibrant participant observation strategies, a constant in the narrative voice of this work. Aside from being in direct dialogue with hip-hop studies scholarship, a probable use for this book could be for specialized topics of cultural politics or critical gender studies; it can also be featured in more advanced undergraduate courses, perhaps with other materials on Cuban, Caribbean and North American historical, social and political contexts.

2 As the author proposes in the introduction, this text focuses on the "emergence and activism of the CUHHM as a formative element in the emergence of localized Black identity politics in Cuba during the Special Period (1989 to the early 2000s)" (p. 8). Additionally, by positioning Cuba as a primary factor in the configuration of Black identity within the Americas, the sophisticated analysis presented in Cuban Underground 
Hip-hop confirms the leading role of Black Cuban politics throughout the veins of the African diaspora.

3 In the introduction, Dr. Saunders presents the critical route that readers will encounter throughout the book. It first analyses how different countries in the Americas have engaged in the racialization of culture to legitimate race-based social inequality, in which culture and race are used as equivalents. Something still present today. By mentioning the first generation of members belonging to the Cuban Underground HipHop Movement, the next part reveals how underground artists structure cultural politics and art-based activism in the Spanish Caribbean and Spanish speaking countries of Latin America. The following subsections in the introduction recollect how Afro-descendant people in the American hemisphere, Cubans in the case if this book, use hip-hop "to challenge the exclusion of African culture and worldviews in the articulation of a Eurocentric Western modernity" (p. 18). The final part of the introduction covers a necessary selection of topics related to the vast field of hip-hop studies; from 'Hip-hop as a Black Public Sphere,' to the significance of blackness, Latin@ness, and Africanness in Hip-hop studies, to intersectional analyses of hip-hop feminism. In her notes (p.325), Dr. Saunders mentions a recent movement in the United States to replace the letter "o" for "@” in order to deactivate the masculinized versions of some Spanish words that imply gender neutrality. Beyond the traditional gender binaries of Spanish, the use of “@” includes masculine, feminine, and other genders.

Chapter 2 discusses historical dimensions of race and cultural politics in Cuba. In this section, the author touches on the socialization processes of culture in the Caribbean island. The political period that started after 1959 serves as a departing point to study the cultural sphere that contextualizes the creative activism done by CUHHM members. A strength of the chapter is the comparison between Nueva Trova artists, who were socially active in the sixties, and Cuban hip-hop artists. Using anti-racist, anticapitalist, and anti-imperialist ideologies; both music genres were able to point out racism as an essential obstacle to directly tackle in Cuban society. And although Nueva Trova emerged from white middle classes in Cuba, differently from the Black subject position from which Cuban hip-hop speaks from; both share Cuban revolution ideals and question the aesthetic debates that define them as "low culture" (p. 76). In its integrity, Dr. Saunders included "The Final Declaration of the First Cuban Hip-Hop Symposium," which "captures the spirit, aims, and social tensions of the previous generations of socially critical musicians and also reflects the movement's initial equation with Nueva Trova in the national media" (p. 100).

5 Furthermore, in this chapter the author describes the meeting between proactive Cuban artist Ariel Hernández and US-based, social justice platform Stress Magazine editor Alan Ket, a breaking point in the history of Latin American hip-hop. The result of this encounter is the Cuban annexation to New York's Black August Hip-hop Project, an international cultural-activist project that strives to support marginalized culture and help in the struggle and recognition for human rights.

Chapter 3 considers how artists challenge racism in Cuba. It focuses on the mobilization that the Cuban Underground Hip-hop Movement organized to question racial identity politics and the continual social asymmetry that prevails in the Caribbean island. The social challenge that artists from the CUHHM articulated is still at the center of the post-Special Period Black identity politics that today continues to fight anti-Black racism. The chapter also touches on the formation of radical youth/Black aesthetics 
through the symbols and ideologies of the CUHHM. To then follow the connection between Cuban rap artivists and their NYC peers from the 1970s and 1980s: "Both populations had limited access to material resources and were able to produce living culture and knowledge from little material means" (p. 117). Also, based on a 2004 hiphop documentary film produced by Ricardo Bacallao, a member of the Cuban alternative arts scene, this chapter touches on the tension generated by the interpretation that Geoff Baker, a British scholar that also specializes in Cuban hip-hop, did of the Cuban racial context through the film. Using the author's words, Baker's focus "is primarily on the US-Cuban relations and does not situate Cuban hip-hop discourses within their regional context" (p. 85). Dr. Sounders' critique, which can be applied to most of Latin American countries, rests on the idea that Caribbean and Latin American hip-hop scenes are not one-dimensional narratives. Opposite to Dr. Baker's argument, in which he sees race as an obstacle to a nuanced study of daily life in Cuba, the author sustains that the lens of race is essential to "understanding culture in the Americas. To ignore race would be to ignore one of the primary ways (subtly or not) in which Americans understand and experience reality" (p. 85).

7 Chapter 4 provides a thorough examination of the "racial fluidity" discourse in Cuba and the Americas. As many have argued, this discussion has merged into the social structures of Latin America and the Caribbean to the point that today this dynamic continues to oppress people of African or indigenous descent. Words like mulat@ness, blackness, whiteness, or mestizo are at the center of the racial intersection structure in Cuba, they have diverse meanings and can exponentiate their symbolism by complementing each other. In the last pages of this chapter, Dr. Saunders focuses on the importance of studying what people do with the language of race and racism. The idea of (marginalized) Cubans actively constructing language to cover their necessities and discern their own experiences is contrary to what other scholars have done. Which is, according to the author, just an analysis of the sign (the language of race and racism) itself, not what people elaborate with it.

8 In Chapter 5, Dr. Saunders dives into the different forms that CUHHM activists use to transform and redefine certain words and ideas. She offers "insight into the agenda of artivists who interrogate and employ terminologies as a means of articulating and defining terms of their own political struggle" (p. 42). Insights provided by the author help to understand the type of agency that rap artists have in Cuba. By manipulating and questioning specific terminologies, Cuban artists have a very proactive role in defining the conditions of their own social and political endeavors.

Chapter 6 engages with the social and economic context that Black Cuban women faced after the Special Period of the nineties. This chapter studies the gendered debates triggered by the Cuban hip-hop feminists' incursion into racism, sexism and heteronormativity. Directly connected, the following chapter centers on the case of Las Krudas CUBENSI, a hip-hop duo that has favored a very progressive gendered agenda. Like others have mentioned, the hip-hop identities of Las Krudas have been constructed around their identity as black lesbians. Chapter 7 is fully dedicated to them, queer critique, and black feminism.

10 As a young scholar, my criticisms of this work are almost inexistent. If some, certain redundancy could be detected. I wonder how a group like Las Krudas CUBENSI thinks about identity politics after moving from Cuba to the US state of Texas. In that sense, some sectors in academia compare Las Krudas to Orishas, another Cuban hip-hop outfit 
that partially changed its residency to France. Moreover, at the time this review was written, it is still tough to think of Cuban women from younger generations that are using hip-hop as a vehicle of expression and identity configuration. Equally, the absence of substantial analysis and references to other essential elements of the hiphop culture like brake-dancing, turntablism, or graffiti writing may leave some readers frustrated. Same with how reggaeton is discussed in the book. Dr. Saunders touches on the topic briefly $(188-189,302)$, but at this time, when reggaeton rhythms are at the center of the mainstream pop music spheres, a more in-depth investigation of how hiphop and reggaeton can coexist in the Caribbean is not only appealing but necessary.

11 Finally, Cuban Underground Hip-hop includes lyrics, pictures, album covers, flyers, and different testimonies from diverse members of the Cuban hip-hop community between 1998 and 2006. Interviews were made in Spanish, and the reader can see both the Spanish transcription and the English translation. As a native Spanish speaker myself, I thought translations could have been better. Same with interview transcripts, some make little sense when read in Spanish. Corresponding transcription and translation processes were used with the lyrics selected.

Dr. Saunders' analysis is no stranger to the impact that global forces and their transnational capitalist flows in the local context of Cuban hip-hop have had. The tension between globalized trends and local constructions of identity are a consistent part of this book. The author masterfully demonstrates how Cuban hip-hop artistactivists were never passive consumers who just integrated the US race discourse found in the first generations of American hip-hop. Dr. Saunders presents Cuban artivists as active people continually dueling with both colonial legacy and contemporary conversations of identity politics.

\section{AUTHORS}

\section{CARLOS DÁVALOS}

Carlos Dávalos is a freelance journalist, and graduate student/researcher. Carlos was born and raised in Mexico City. His research is influenced by Mexico's society, music, and popular culture. In 2009 he received a professional master's degree from UC Berkeley's Graduate School of Journalism for his work on Mexico City's illegal, underground drug-rehab facilities - anexos. In 2017 he received a master's degree from UT Austin's Ethnomusicology Department for his work on Mexico's hip-hop movement. Previously, he covered Mexico City's music scene and taught at the Communications Department in Mexico City's Universidad Iberoamericana. From 2005 to 2016, Carlos co-founded and co-hosted Scratchamama, one of the first hip-hop FM radio shows in the country. The radio program was central to Mexican hip-hop's development, popularization, and promotion. In 2010, Carlos founded an independent record label called Discos Cuchillo to publish underground music and literary works from Mexico City and Puebla. And from 2014 to 2018, Carlos was a recipient of Mexico's CONACyT (Consejo Nacional de Ciencia y Tecnología) international scholarship. In Fall 2018, Carlos will join UW Madison's Mass Communications \& Journalism PhD program. Carlos' academic interests include the impact of technology, 
transnationalism, nationalism, and gender in Mexican mainstream. media and popular music (Mexican hip-hop specifically). 